\title{
Influence of selected feed supplements on the growth and health of calves depending on the sex, season of birth, and number of the dam's lactations
}

\author{
Luboš Zábranský ${ }^{1}$, Miloslav Šoch ${ }^{1}$, Jan Brouček $^{2}$, Pavel Novák ${ }^{1}$, Petr Tejml ${ }^{1}$, \\ Dana Jirotková ${ }^{1}$, Eva Petrášková1, Marcela Raabová1, Luboš Smutný ${ }^{1}$, Zuzana Jahnová3, \\ Š́rka Smutná ${ }^{1}$ \\ ${ }^{1}$ University of South Bohemia in České Budějovice, Faculty of Agriculture, \\ Department of Animal husbandry sciences, České Budějovice, Czech Republic \\ ${ }^{2}$ Research Institute of Animal Production Nitra, Luzianky, Slovakia \\ ${ }^{3}$ University of South Bohemia in České Budějovice, Faculty of Agriculture, \\ Department of Plant production, České Budějovice, Czech Republic \\ Received September 23, 2014 \\ Accepted April 1, 2015
}

\begin{abstract}
The aim of this study was to prove the hypothesis that the growth and health of calves are dependent on feed supplements with an antidiarrhoeic effect, in relation to sex, season of birth, and number of the dam's lactations. A total of 186 calves were included in the experiment. After birth the calves were divided into three treatment groups: Ascophyllum nodosum (brown seaweed hydrolyzate, prebiotics), Lactobacillus sporogenes (probiotics), and the control group. All calves were weighed within two h after birth. The growth and health were investigated from the birth to the fourth week of age. Compared to the control, a significant effect of applied feed supplements was found in the Lactobacillus sporogenes group in the body weight at 28 days of life $(P<0.01)$ and in the average daily gains $(P<$ $0.001)$. Differences between sexes were found in the body weight at birth $(P<0.001)$ and in the body weight at 28 days of life $(P<0.01)$. The effect of the season of birth was recorded in the average daily gains $(P<0.01)$. The effect of the number of the dam's lactations on calf was proved in body weights at birth and 28 days of life $(P<0.01)$. The interaction between treatment and sex $(P<0.05)$, and between treatment and season of birth $(P<0.01)$ were calculated in the average daily gains. We concluded from the analysis that only the use of Lactobacillus sporogenes had a positive influence on increasing the growth. Neither of the two supplements had a positive impact on the health of calves.
\end{abstract}

Calf, diarrhoea, microbiota, nutrition, probiotics

In the intensive management system of farm animals, especially in calf rearing without the dam, the natural acquisition of autochthonous microflora is drastically reduced by changing the intestinal environment and allowing pathogens to colonize the microbiota (Rosmini et al. 2004). The incidence of metabolic disorders in dairy calves in the Czech Republic represents a highly actual problem and one of the important factors influencing this condition is insufficient care for and the related insufficient colostral nutrition of calves (Podhorský et al. 2007; Šlosárková et al. 2014). As proved by many studies (Nogalski 2003; Svensson et al. 2003; Svensson and Hultgren 2008; Kamal et al. 2014), the growth of live body weight and occurrence of diarrhoeas in dairy calves are influenced also by the dam's parity and the season of birth.

The importance of probiotics and prebiotics is based on their ability to stabilize the inner microbiota and to influence the calf's health and welfare. Positive effects of Ascophyllum nodosum on the reduction of the pathogen $E$. coli $\mathrm{O} 157: \mathrm{H} 7$ were proven in cattle and sheep (Bach et al. 2008). The effect of Lactobacillus sporogenes on Salmonella Dublin was verified by Frizzo et al. (2011); the effect of Lactobacillus on the started feed intake and

Address for correspondence:

Ing. Luboš Zábranský, Ph.D.

Department of Animal husbandry sciences, Faculty of Agriculture

University of South Bohemia in Ceské Budějovice

Phone: +420608260452

Studentská 1668, 37005 České Budějovice, Czech Republic 
on the weight gain by Higginbotham and Bath (1993); and the effect of Lactobacillus acidophilus on the occurrence of calf diarrhoeas by Tarboush et al. (1996).

Regular administration of probiotics may help to create stable and balanced intestinal microflora that will improve the calf's health (Soto et al. 2011). Probiotics are viable microorganisms exerting a favourable effect on the host's health by improving its intestinal microbial balance (Kaur et al. 2002). Probiotics are competitors for pathogenic microorganisms in the utilization of intestinal space and nutrients, they reduce intestinal $\mathrm{pH}$ by the production of organic acids, release bacteriocins and hydrogen peroxide, and stimulate the host's immunity system. Probiotics may reduce the risk of infections and intestinal disorders (Ewaschuk et al. 2004). To maintain a changeless, high level of probiotics in the digestive tract of calves, administration of these products should continue for as long as possible (Ohashi et al. 2009). The inclusion of a probiotic in the feed ration decreases the amount of pathogenic strains of Escherichia coli by $36 \%$ in the faeces of sheep and heifers (Braden et al. 2004). After the administration of a probiotic to grazing dairy cows in the summer season the temperature of their body surface decreases, which contributes to alleviation of the heat stress of animals (Pompeu et al. 2011).

Prebiotics are selectively fermented components facilitating specific changes in the large intestine, both in the composition and growth and in the activity of bacteria in the digestive tract. Metabolically, the large intestine is one of the most active organs in the body; therefore, the intake of prebiotic products has a significant influence on its function (Wang 2009). The use of prebiotics showed a positive influence on the production of short-chain fatty acids in the intestinal microflora (Scheid et al. 2013).

Feed supplements will have a positive effect on reducing the incidence of diarrhoeal disease and improving the health status of calves. The aim of this study was to investigate the hypothesis that the growth and health in calves are affected by probiotic and prebiotic feed supplements with an anti-diarrhoeic effect, in relation to sex, season of birth, and number of the dam's lactations.

\section{Materials and Methods}

A total of 186 Holstein calves (62 in the Lactobacillus sporogenes group, 62 in the Ascophyllum nodosum group, and 62 in the control group) from one herd of dairy cows were included in the experiment. After birth the calves were randomly divided into 3 treatment groups: Group 1 - Ascophyllum nodosum, Group 2 - Lactobacillus sporogenes, and control Group 3. The calves were separated from the dams on the first day after birth and then they were reared in individual littered hutches till weaning. They received colostrum and mother's milk ad libitum $\times 3$ a day from a bucket with a nipple from day 2 to 4 . From day 5 they received $4.5 \mathrm{~kg}$ of milk replacer per day divided into 3 portions, a starter mixture (crushed wheat $20 \%$, crushed barley $15 \%$, whole maize grains $10 \%$, whole oat grains $19.5 \%$, extracted rapeseed meal $15 \%$, extracted soybean meal 15\%, Tetravit (Nita-Farm, Saratov, Russia) - vitamin-mineral premix 5\%, calcium $0.5 \%$ ) and alfalfa hay ad libitum until weaning. Colostrum and subsequently milk replacer were administered to calves in plastic buckets with nipples that were fitted in the hutches at a height of $40 \mathrm{~cm}$ above the ground. The calves had a free access to drinking water for the entire experimental period. The experiment was conducted from February 2011 to January 2013.

The Ascophyllum nodosum experimental group received orally $5 \mathrm{ml}$ of hydrolyzate from brown seaweeds in addition to the colostrum and milk replacer. The Lactobacillus sporogenes experimental group received orally 1 tablet of probiotics added to the colostrum at first and then to the milk replacer and thoroughly mixed. The formulation of one tablet of probiotics was $4 \times 10^{7}$ Lactobacillus sporogenes. Experimental groups were administered these feed supplements $\times 1$ a day (at the second feeding). Both supplements were applied to experimental groups within the first fortnight after the birth. The control group received a non-supplemented diet, consisted $1.5 \mathrm{~kg}$ of milk replacer per feeding (totally $4.5 \mathrm{~kg}$ ), starter mixture and alfalfa hay ad libitum. All calves were observed until day 28 of life.

All calves were weighed within two hours after birth and then they were weighed regularly every week. Classical method for the evaluation and expression of diarrhoea according to Larson et al. (1977) was used. Observations of faeces and health condition was evaluated twice a day together with rectal temperature measurements at the time of feeding. Respiratory condition was assessed by the symptom type (normal, runny nose, heavy breathing, and cough - moist or dry). Other frequency of cough (possible respiratory disorder) was assessed as occasional, 
intermittent, or persistent. Operators observed the condition of hair and eyes (dullness and brightness) and signs of dehydration (sunken eyes, inelastic skin, and prostration).

During long lasting diarrhoeal diseases calves from all treatment groups were treated using the preparation Argivo Se (Deltavit, France) at $40 \mathrm{~g}$ per day.

The data were analyzed using a General Linear Model ANOVA (four ways with the interactions) of the statistical package STATISTICS 10 (Analytical Software, Tallahassee, FL, USA). Factors were evaluated of the treatment group $(1-$ Ascophyllum nodosum, $\mathrm{N}=62,2$ - Lactobacillus sporogenes, $\mathrm{N}=62 ;$ and $3-\mathrm{control}, \mathrm{N}=$ 62); sex (male, $\mathrm{N}=87$; female, $\mathrm{N}=99$ ), season of the birth ( 1 - spring, $\mathrm{N}=35 ; 2$ - summer, $\mathrm{N}=61 ; 3-$ fall, $\mathrm{N}$ = 53; and 4 - winter, $\mathrm{N}=37$ ), and number of the dam's lactations (first lactation, $\mathrm{N}=58 ; 2$ - second and higher lactation, $\mathrm{N}=128$ ). Normality of data distribution was evaluated by Wilk-Shapiro/Rankin Plot procedure. All data conformed to a normal distribution. Significant differences between groups were tested by Comparisons of Mean Ranks. Values are expressed as means \pm SD and differences were considered significant at $P<0.05$.

\section{Results}

The calves from the treatment group 2 (probiotics) reached the highest live body weight at 28 days. Differences were significant in comparison to group 1 and control group (53.77 $\pm 6.18 \mathrm{~kg}$ vs $51.27 \pm 4.71 \mathrm{~kg}, P<0.05 ; 53.77 \pm 6.18 \mathrm{~kg}$ vs $50.15 \pm 5.61 \mathrm{~kg}, P<0.01)$. Similarly, the average daily weight gains over the experimental period were also the highest in the probiotics group $2(0.39 \pm 0.09 \mathrm{~kg}$ vs $0.33 \pm 0.10 \mathrm{~kg}, P<0.05 ; 0.39 \pm 0.09 \mathrm{~kg}$ vs 0.30 $\pm 0.10 \mathrm{~kg}, P<0.01$ ) (Table 1).

In our study significant effects of sex and season of the birth on growth intensity of calves (Tables 2 and 3) were found. Males were heavier at birth and at 28 days of life compared to females $(43.00 \pm 5.05 \mathrm{~kg}$ vs $40.24 \pm 4.67 \mathrm{~kg}, P<0.001 ; 53.13 \pm 6.22 \mathrm{~kg}$ vs $50.50 \pm 4.94 \mathrm{~kg}$, $P<0.01$ ). Calves born during the summer period had the lowest average daily gains over the observed period from the first week to the termination of the experiment $(0.30 \pm 0.08 \mathrm{~kg}$ compared to $0.36 \pm 0.13 \mathrm{~kg}, 0.36 \pm 0.11 \mathrm{~kg}$, and $0.36 \pm 0.11 \mathrm{~kg} ; P<0.05)$.

Table 1. The effect of applied supplements on the growth and morbidity of calves.

\begin{tabular}{|c|c|c|c|c|c|c|}
\hline \multirow{3}{*}{ Variables } & \multirow{3}{*}{$\mathrm{N}$} & \multicolumn{3}{|c|}{ Treatment groups } & \multirow{3}{*}{$P$} & \multirow{3}{*}{ Significance } \\
\hline & & $\begin{array}{l}\text { Ascophyllum } \\
\text { nodosum }\end{array}$ & $\begin{array}{l}\text { Lactobacillus } \\
\text { sporogenes }\end{array}$ & Control & & \\
\hline & & $\overline{\mathrm{x}} \pm \mathrm{SD}$ & $\overline{\mathrm{x}} \pm \mathrm{SD}$ & $\overline{\mathrm{x}} \pm \mathrm{SD}$ & & \\
\hline BW at birth (kg) & 186 & $41.49 \pm 5.11$ & $42.11 \pm 5.28$ & $40.99 \pm 4.70$ & 0.4642 & \\
\hline $\mathrm{BW}$ in $28^{\text {th }}$ day $(\mathrm{kg})$ & 186 & $51.27 \pm 4.71$ & $53.77 \pm 6.18$ & $50.15 \pm 5.61$ & $0.0012 * *$ & $2: 3^{* *}, 1: 2^{*}$ \\
\hline $\begin{array}{l}\text { ADG from birth to } \\
28^{\text {th }} \text { day }(\mathrm{kg})\end{array}$ & 186 & $0.33 \pm 0.10$ & $0.39 \pm 0.09$ & $0.30 \pm 0.10$ & 0.0000 & $2: 3^{* *}, 1: 2^{*}$ \\
\hline $\begin{array}{l}\text { Number of } \\
\text { diarrhoeas, Week } 1\end{array}$ & 186 & $0.19 \pm 0.40$ & $0.15 \pm 0.36$ & $0.31 \pm 0.46$ & 0.0813 & \\
\hline $\begin{array}{l}\text { Number of } \\
\text { diarrhoeas, Week } 2\end{array}$ & 186 & $0.19 \pm 0.40$ & $0.16 \pm 0.37$ & $0.24 \pm 0.43$ & 0.5311 & \\
\hline $\begin{array}{l}\text { Number of } \\
\text { diarrhoeas, Week } 3\end{array}$ & 186 & $0.05 \pm 0.22$ & $0.03 \pm 0.18$ & $0.02 \pm 0.13$ & 0.6006 & \\
\hline $\begin{array}{l}\text { Number of } \\
\text { diarrhoeas, Week } 4\end{array}$ & 186 & $0.00 \pm 0.00$ & $0.00 \pm 0.00$ & $0.00 \pm 0.00$ & M & \\
\hline $\begin{array}{l}\text { Duration of } \\
\text { diarrhoea (day) }\end{array}$ & 186 & $1.71 \pm 3.46$ & $1.27 \pm 3.04$ & $2.40 \pm 3.61$ & 0.1743 & \\
\hline $\begin{array}{l}\text { Total number } \\
\text { of diarrhoeas }\end{array}$ & 186 & $0.23 \pm 0.42$ & $0.16 \pm 0.37$ & $0.34 \pm 0.48$ & 0.0657 & \\
\hline
\end{tabular}

$* P<0.05 ; \quad * * P<0.01 ; \quad \mathrm{SD}=$ standard deviation; $\mathrm{ADG}=$ average daily gains; $\mathrm{BW}=$ body weight $P=$ significance; $\mathrm{N}=$ number $(1-$ Ascophyllum nodosum, $\mathrm{N}=62,2$ - Lactobacillus sporogenes, $\mathrm{N}=62$; and $3-$ control, $\mathrm{N}=62)$;

$\mathrm{M}=$ missing value 
Table 2. The effect of sex on the growth and morbidity of calves.

\begin{tabular}{|c|c|c|c|c|c|c|}
\hline \multirow{3}{*}{ Variables } & \multirow{3}{*}{$\mathrm{N}$} & \multicolumn{3}{|c|}{ Sex } & \multirow{3}{*}{ Max } & \multirow{3}{*}{$P$} \\
\hline & & Male & Female & Min & & \\
\hline & & $\overline{\mathrm{x}} \pm \mathrm{SD}$ & $\overline{\mathrm{x}} \pm \mathrm{SD}$ & & & \\
\hline BW at birth $(\mathrm{kg})$ & 186 & $43.00 \pm 5.05$ & $40.24 \pm 4.67$ & 27.00 & 53.00 & $0.0002 * * *$ \\
\hline BW in $28^{\text {th }}$ day $(\mathrm{kg})$ & 186 & $53.13 \pm 6.22$ & $50.50 \pm 4.94$ & 34.00 & 68.00 & $0.0016^{* *}$ \\
\hline $\begin{array}{l}\text { ADG from birth } \\
\text { to } 28^{\text {th }} \text { day }(\mathrm{kg})\end{array}$ & 186 & $0.34 \pm 0.12$ & $0.34 \pm 0.09$ & 0.10 & 0.80 & 0.7651 \\
\hline $\begin{array}{l}\text { Number of diarrhoeas, } \\
\text { Week } 1\end{array}$ & 186 & $0.25 \pm 0.44$ & $0.18 \pm 0.39$ & 0.00 & 1.00 & 0.2416 \\
\hline $\begin{array}{l}\text { Number of diarrhoeas, } \\
\text { Week } 2\end{array}$ & 186 & $0.25 \pm 0.44$ & $0.15 \pm 0.36$ & 0.00 & 1.00 & 0.0849 \\
\hline $\begin{array}{l}\text { Number of diarrhoeas, } \\
\text { Week } 3\end{array}$ & 186 & $0.01 \pm 1.10$ & $0.05 \pm 0.22$ & 0.00 & 1.00 & 0.1344 \\
\hline $\begin{array}{l}\text { Number of diarrhoeas, } \\
\text { Week } 4\end{array}$ & 186 & $0.00 \pm 0.00$ & $0.00 \pm 0.00$ & 0.00 & 0.00 & M \\
\hline $\begin{array}{l}\text { Duration of diarrhoea } \\
\text { (day) }\end{array}$ & 186 & $1.99 \pm 3.45$ & $1.63 \pm 3.35$ & 0.00 & 16.00 & 0.4686 \\
\hline $\begin{array}{l}\text { Total number } \\
\text { of diarrhoeas }\end{array}$ & 186 & $0.28 \pm 0.45$ & $0.21 \pm 0.41$ & 0.00 & 1.00 & 0.3137 \\
\hline
\end{tabular}

$* * P<0.01 ; * * * P<0.001 ; \quad \mathrm{SD}=$ standard deviation; $\mathrm{ADG}=$ average daily gains; $\mathrm{BW}=$ body weight; $P=$ significance; $\mathrm{N}=$ number (male, $\mathrm{N}=87$; female, $\mathrm{N}=99$ ), $\mathrm{M}=$ missing value; $\mathrm{Min}=\operatorname{minimum}$; $\mathrm{Max}=\operatorname{maximum}$

Table 3. The effect of birth season on the growth and morbidity of calves.

\begin{tabular}{|c|c|c|c|c|c|c|}
\hline \multirow{3}{*}{ Variables } & \multicolumn{4}{|c|}{ Birth season } & \multirow{3}{*}{$P$} & \multirow{3}{*}{ Significance } \\
\hline & 1 & 2 & 3 & 4 & & \\
\hline & $\overline{\mathrm{x}} \pm \mathrm{SD}$ & $\overline{\mathrm{X}} \pm \mathrm{SD}$ & $\overline{\mathrm{x}} \pm \mathrm{SD}$ & $\overline{\mathrm{x}} \pm \mathrm{SD}$ & & \\
\hline BW at birth $(\mathrm{kg})$ & $41.91 \pm 5.22$ & $41.50 \pm 4.99$ & $40.99 \pm 5.01$ & $42.00 \pm 5.07$ & 0.7706 & \\
\hline $\mathrm{BW}$ in $28^{\text {th }}$ day $(\mathrm{kg})$ & $52.86 \pm 6.58$ & $50.39 \pm 5.16$ & $51.83 \pm 4.90$ & $52.74 \pm 6.52$ & 0.1147 & \\
\hline ADG from birth to & & & & & \multicolumn{2}{|c|}{$2: 3^{* *}, 1: 2^{*}$} \\
\hline $28^{\text {th }}$ day $(\mathrm{kg})$ & $0.36 \pm 0.13$ & $0.30 \pm 0.08$ & $0.36 \pm 0.11$ & $0.36 \pm 0.11$ & $0.0012 * *$ & $2: 4^{*}$ \\
\hline $\begin{array}{l}\text { Number of diarrhoeas, } \\
\text { Week } 1\end{array}$ & $0.11 \pm 0.32$ & $0.25 \pm 0.43$ & $0.23 \pm 0.42$ & $0.24 \pm 0.44$ & 0.4518 & \\
\hline $\begin{array}{l}\text { Number of diarrhoeas, } \\
\text { Week } 2\end{array}$ & $0.17 \pm 0.38$ & $0.20 \pm 0.40$ & $0.19 \pm 0.40$ & $0.24 \pm 0.44$ & 0.8855 & \\
\hline $\begin{array}{l}\text { Number of diarrhoeas, } \\
\text { Week } 3\end{array}$ & $0.09 \pm 0.28$ & $0.03 \pm 0.18$ & $0.02 \pm 0.14$ & $0.00 \pm 0.00$ & 0.194 & \\
\hline Number of diarrhoeas, & & & & & & \\
\hline Week 4 & $0.00 \pm 0.00$ & $0.00 \pm 0.00$ & $0.00 \pm 0.00$ & $0.00 \pm 0.00$ & M & \\
\hline $\begin{array}{l}\text { Duration of diarrhoea } \\
\text { (day) }\end{array}$ & $1.40 \pm 3.24$ & $1.77 \pm 3.30$ & $2.00 \pm 3.74$ & $1.92 \pm 3.24$ & 0.8701 & \\
\hline $\begin{array}{l}\text { Total number } \\
\text { of diarrhoeas }\end{array}$ & $0.17 \pm 0.38$ & $0.26 \pm 0.44$ & $0.25 \pm 0.43$ & $0.27 \pm 0.45$ & 0.7453 & \\
\hline
\end{tabular}

$* P<0.05 ; * * P<0.01 ; \mathrm{SD}=$ standard deviation; $\mathrm{ADG}=$ average daily gains; $\mathrm{BW}=$ body weight; $1=$ spring, $2=$ summer, $3=$ fall, $4=$ winter; $P=$ significance; $\mathrm{N}(1-\operatorname{spring}, \mathrm{N}=35$; 2 - summer, $\mathrm{N}=61 ; 3$ - fall, $\mathrm{N}=53$; and 4 - winter, $\mathrm{N}=37$ ), $\mathrm{M}=$ missing value 
Table 4. The influence of the number of mother's lactations on the growth and morbidity of calves.

\begin{tabular}{|c|c|c|c|c|c|c|}
\hline \multirow{3}{*}{ Variables } & \multirow{3}{*}{$\mathrm{N}$} & \multicolumn{4}{|c|}{ Number of lactations } & \multirow{3}{*}{$P$} \\
\hline & & 1 & 2 & Min & Max & \\
\hline & & $\overline{\mathrm{x}} \pm \mathrm{SD}$ & $\overline{\mathrm{x}} \pm \mathrm{SD}$ & & & \\
\hline BW at birth (kg) & 186 & $40.10 \pm 4.80$ & $42.18 \pm 5.01$ & 27.00 & 53.50 & \\
\hline $0.0084 * *$ & & & & & & \\
\hline $\mathrm{BW}$ in $28^{\text {th }}$ day $(\mathrm{kg})$ & 186 & $49.99 \pm 5.64$ & $52.52 \pm 5.59$ & 34.00 & 68.00 & \\
\hline $0.0049 * *$ & & & & & & \\
\hline ADG from birth to & & & & & & \\
\hline $28^{\text {th }}$ day $(\mathrm{kg})$ & 186 & $0.33 \pm 0.10$ & $0.34 \pm 0.11$ & 0.10 & 0.80 & 0.3686 \\
\hline Number of diarrhoeas, & & & & & & \\
\hline Week 1 & 186 & $0.24 \pm 0.43$ & $0.20 \pm 0.40$ & 0.00 & 1.00 & 0.5589 \\
\hline $\begin{array}{l}\text { Number of diarrhoeas, } \\
\text { Week } 2\end{array}$ & 186 & $0.17 \pm 0.38$ & $0.21 \pm 0.40$ & 0.00 & 1.00 & 0.5446 \\
\hline $\begin{array}{l}\text { Number of diarrhoeas, } \\
\text { Week } 3\end{array}$ & 186 & $0.02 \pm 0.13$ & $0.04 \pm 0.19$ & 0.00 & 1.00 & 0.438 \\
\hline $\begin{array}{l}\text { Number of diarrhoeas, } \\
\text { Week } 4\end{array}$ & 186 & $0.00 \pm 0.00$ & $0.00 \pm 0.00$ & 0.00 & 0.00 & M \\
\hline $\begin{array}{l}\text { Duration } \\
\text { of diarrhoea (day) }\end{array}$ & 186 & $1.78 \pm 3.31$ & $1.80 \pm 3.44$ & 0.00 & 16.00 & 0.9573 \\
\hline $\begin{array}{l}\text { Total number } \\
\text { of diarrhoeas }\end{array}$ & 186 & $0.24 \pm 0.43$ & $0.24 \pm 0.43$ & 0.00 & 1.00 & 0.9906 \\
\hline
\end{tabular}

$* P<0.05 ; \quad * * P<0.01 ; \mathrm{SD}=$ standard deviation; $\mathrm{ADG}=$ average daily gains; $\mathrm{BW}=$ body weight; $1=$ primaparous, 2 = multiparous; $P=$ significance; $\mathrm{N}=$ number (and number of mother's lactations (first lactation, $\mathrm{N}=58 ; 2$ - second and higher lactation, $\mathrm{N}=128) ; \mathrm{M}=$ missing value; $\mathrm{Min}=$ minimum; $\mathrm{Max}=\operatorname{maximum}$

Calves born to primiparous dams showed significantly lower live body weights at birth, also at the last weighing on day 28 compared to calves from older cows $(40.10 \pm 4.80 \mathrm{~kg}$ vs $42.18 \pm 5.01 \mathrm{~kg}, P<0.01 ; 49.99 \pm 5.64 \mathrm{~kg}$ vs $52.52 \pm 5.59 \mathrm{~kg}, P<0.01)$ (Table 4).

The interaction between treatment and sex $(P<0.05)$, and between treatment and season of the birth $(P<0.01)$ were calculated in the average daily gains.

Neither Ascophyllum nodosum (treatment group 1) nor Lactobacillus sporogenes (treatment group 2) supplement had the influence on scour incidence. It affected neither of the indices (number of diarrhoeas in calves in each week and totally, and duration of scours (Table 1). No calf from our experiment died or was culled for bad health. The faeces had liquid consistency during the first weeks and then became firm. In the first week the colour was yellow, later on green.

\section{Discussion}

In the present work we studied the impacts of two feed supplements. However, a significant effect was shown only in treatment group 2 which received probiotics. These calves had the most intensive increase of live body weight.

A positive influence of the use of Lactobacillus sporogenes on the weight gains of calves was also reported by Fuller (1989), Tarboush et al. (1996), Schneider et al. (2004), Timmerman et al. (2005), Frizzo et al. (2010), and Soto et al. (2014). A low or no influence on the increase in weight gains of animals in the group with Ascophyllum 
nodosum may be a result of the availability of a sufficient amount of prebiotics in common feed like oats, barley, and wheat (Gaggía et al. 2010).

In our study we found significant effects of sex and season of the birth on growth intensity of calves. Males were heavier at birth and at 28 days of life than females.

Kertz et al. (1997) reported in their study different weight gains in young bulls and heifers; the gains in young bulls were higher by $8.5 \%$ compared to heifers; similar results were found out also by Dhakal et al. (2013).

Calves born during the summer period had the lowest average daily gains over the observed period from the first week to the termination of the experiment. The main advantage of the hutch rearing of calves is the minimized risk of disease transfer from calf to calf. However, the temperature stress is generally disregarded (Coleman et al. 1996; Spain and Spiers 1996). Our research has confirmed the findings of many authors that high air temperature can also cause stress in calves (Mader and Davis 2004; Broucek et al. 2009). The growth of live body weight of calves was also influenced by the factors of birth seasonality and the number of the dam's lactations. The interaction between treatment and sex, and between treatment and season of birth were recorded in the average daily gains evaluation. It means that treatment by probiotics can be positively or negatively influenced by the sex of treated calves, and also by the season of birth.

Calves of young dams displayed lower live body weights than calves of older dams. Kertz et al. (1997), Svensson et al. (2003), and Dhakal et al. (2013) identically reported higher weight gains in calves born to mothers at the second and higher lactations.

The use of Ascophyllum nodosum has no effect on improving the growth and health of calves. The results showed no positive effect of either observed supplement (Ascophyllum nodosum or Lactobacillus sporogenes) on health and especially, on scour incidences.

We concluded from the analysis, that the effect of the probiotic Lactobacillus sporogenes was manifested only in the increased growth of calves. The action and effect of this feed supplement may be affected by the season of birth and the sex of calves.

\section{Acknowledgement}

This study was supported by grant projects NAZV QJ1210144, NAZV QJ1210375 and GAJU 020/2013/Z.

\section{References}

Bach SJ, Wang Y, McAllister TA 2008: Effect of feeding sun-dried seaweed (Ascophyllum nodosum) on fecal shedding of Escherichia coli $\mathrm{O} 157: \mathrm{H} 7$ by feedlot cattle and on growth performance of lambs. Anim Feed Sci and Tech 142: 17-32

Braden KW, Blanton JR, Allen VG, Pond KR, Miller MF 2004: Ascophyllum nodosum supplementation: A preharvest intervention for reducing Escherichia coli O157:H7 and Salmonella spp. in feedlot steers. J Food Prot 67: 1824-1828

Broucek J, Kisac P, Uhrincat M 2009: Effect of hot temperatures on the hematological parameters, health and performance of calves. Int J Biometeorol 53: 201-208

Coleman DA, Moss BR, McCaskey TA 1996: Supplemental shade for dairy calves reared in commercial calf hutches in a southern climate. J Dairy Sci 79: 2038-2043

Dhakal K, Maltecca C, Cassady JP, Baloche G, Williams CM, Washburn SP 2013: Calf birth weight, gestation length, calving ease, and neonatal calf mortality in Holstein, Jersey, and crossbred cows in a pasture system. J Dairy Sci 96: 690-698

Ewaschuk JB, Naylor JM, Zello GA 2004: Lactobacillus rhamnosus strain GG is a potential probiotic for calves. Can J Vet Res 68: 249-258

Frizzo LS, Soto LP, Bertozzi E, Zbrun MV, Signorini ML, Sequeira G, Armesto RR, Rosmini MR 2011: Intestinal populations of lactobacilli and coliforms after in vivo Salmonella dublin challenge and their relationship with microbial translocation in calves supplemented with lactic acid bacteria and lactose. Anim Feed Sci Tech 170: $12-20$

Frizzo LS, Soto LP, Zbrun MV, Bertozzi E, Sequeira G, Rodriguez M, Armesto RR, Rosmini MR 2010: Lactic acid bacteria to improve growth performance in young calves fed milk replacer and spray-dried whey powder. Anim Feed Sci Techn 157: 159-167 
Fuller R 1989: Probiotics in man and animals. J Appl Bacteriol 66: 365-378

Gaggía F, Mattarelli P, Biavati B 2010: Probiotics and prebiotics in animal feeding for safe food production. Inter J Food Microb 141: 15-28

Higginbotham GE, Bath DL 1993: Evaluation of Lactobacillus fermentation cultures in calf feeding systems. J Dairy Sci 76: 615-620

Kamal MM, Eetvelde MV, Depreester E, Hostens M, Vandaele L, Opsomer G 2014: Age at calving in heifers and level of milk production during gestation in cows are associated with the birth size of Holstein calves. J Dairy Sci 97: 5448-5458

Kaur IP, Chopra K, Saina A 2002: Probiotics potential pharmaceutical applications. European J Pharm Sci 15: 1-9

Kertz AF, Reutzel LF, Barton BA, Ely RL 1997: Body weight, body condition score, and wither height of prepartum Holstein cows and birth weight and sex of calves by parity. J Dairy Sci 80: 525-529

Larson LL, Owen FG, Albright JL 1977: Guidelines toward more uniformity in measuring and reporting calf experimental data. J Dairy Sci 60: 989-991

Mader TL and Davis MS 2004: Effect of management strategies on reducing heat stress of feedlot cattle; feed and water intake. J Anim Sci 82: 3077-3087

Nogalski Z 2003: Relations between the course of parturition, body weights and measurements of HolsteinFriesian calves. Czech J Anim Sci 48: 51-59

Ohashi Y, Ushida K 2009: Health-beneficial effects of probiotics its mode of action. Anim Sci J 80: 361-371

Podhorský A, Pechová A, Dvořák R, Pavlata L 2007: Metabolic disorders in dairy calves in postpartum period. Acta Vet Brno 76: 45-53

Pompeu LB, Williems JE, Spiers DE, Weaber RL, Ellersieck MR, Sargent KM, Feyerabend NP, Vellios HL, Evans F 2011: Effect of Ascophyllum nodosum on alleviation of heat stress in dairy cows. Prof Anim Sci 27: 181-189

Rosmini MR, Sequeira GJ, Guererro-Legarreta I, Martí LE, Dalla-Santina R, Frizzo L, Bonazza JC 2004: Production of probiotics for animals: importance of using internal intestinal microflora (in Spanish). Mex J Chem Eng 3: 181-191

Scheid MMA, Moreno YMF, Maróstica MR, Pastore GM 2013: Effect of prebiotics on the health of the elderly. Food Res Inter 53: 426-432

Schneieder R, Rosmini MR, Eehrmann M, Vogel R 2004: Identification of lactic acid bacteria form the typical microbiota found in artificial reared calves. FAVE - Ciencias Vet 3: 7-15

Soto LP, Frizzo LS, Avataneo E, Zbrun MV, Bertozzi E, Sequeira G, Signorini ML, Rosmini MR 2011: Design of macrocapsules to improve bacterial viability and supplementation with a probiotic for young calves. Anim Feed Sci and Tech 12: 176-183

Soto LP, Zbruna MV, Frizzo LS, Signorinia ML, Sequeira GJ, Rosmini MR 2014: Effects of bacterial inoculants in milk on the performance of intensively reared calves. Anim Feed Sci Tech 189: 117-122

Spain JN, Spiers DE 1996: Effects of supplemental shade on thermoregulatory response of calves to heat challenge in a hutch environment. J Dairy Sci 79: 639-646

Svensson C, Hultgren J 2008: Associations between housing, management, and morbidity during rearing and subsequent first-lactation milk production of dairy cows in southwest Sweden. J Dairy Sci 91: 1510-1518

Svensson C, Lundborg K, Emanuelson U, Olsson SO 2003: Morbidity in Swedish dairy calves from birth to 90 days of age and individual calf-level risk factors for infectious diseases. Prev Vet Med 58: 179-197

Šlosárková S, Fleischer P, Pěnkava O, Skřivánek M 2014: The assessment of colostral immunity in dairy calves based on serum biochemical indicators and their relationships. Acta Vet Brno 83: 151-156

Tarboush HMA, Saiady MYA, Din AHKE 1996: Evaluation of diet containing lactobacilli on performance, fecal coliform, and lactobacilli of young dairy calves. Anim Feed Sci Tech 57: 39-49

Timmerman HM, Mulder L, Everts H, Van Espen DC, Van Der Wal E, Klaassen G, Rouwers SMG, Hartemink R, Rombouts FM, Beynen AC 2005: Health and growth of veal calves fed milk replacers with or without probiotics. J Dairy Sci 88: 2154-2165

Wang Y 2009: Prebiotics: Present and future in food science and technology. Food Res Inter 42: 8-12 